\title{
EFFECT OF PROCESSING CONDITIONS ON QUALITY OF JUICE EXTRACTED FROM HOG PLUM FRUIT
}

\author{
${ }^{1}$ Olaoye, I.O., ${ }^{2}$ Salako, Y. A., ${ }^{3}$ Odugbose, B. D. and ${ }^{2}$ Owolarafe, O. K. \\ 'Department of Mechanical and Agricultural Engineering, Technical University, Ibadan, Oyo State, Nigeria. \\ ${ }^{2}$ Department of Agricultural and Environmental Engineering, Obafemi Awolowo University, Ile-Ife, Osun State, Nigeria. \\ ${ }^{3}$ Department of Agricultural Engineering, Olabisi Onabanjo University, Ibogun Campus, Ogun State, Nigeria. \\ Corresponding author's email address: salakoyusuf@gmail.com; Tel: +2348132847702 \\ Email address of other authors: OIO-isaac.olaoye@tech-u.edu.ng; OBD-odugbose.babashola@oouagoiwoye.edu.ng; \\ OOK- owolarafe@yahoo.com
}

(Received: $19^{\text {th }}$ November, 2020; Accepted: $12^{\text {th }}$ March, 2021)

\section{ABSTRACT}

\begin{abstract}
The effect of processing conditions such as machine shaft speed, loading and level of ripeness of the Spondias mombin fruit on quality (i.e moisture, ash, fibre, fat and protein contents) of juice extracted were investigated in this study using a newly designed juice extractor for Spondias mombin fruit. The moisture content of the extracted juice was observed to initially decrease as the shaft speed increased from 120 to $130 \mathrm{rpm}$ and then increased with increase in shaft speed from 130 to $150 \mathrm{rpm}$. Increase in loading from 5 to $15 \mathrm{~kg}$ per time increased the moisture content of the juice at different shaft speeds. As the shaft speed and rate of loading per time increases, the ash content of the juice also increases. Increase in shaft speed also increased the fibre, fat and protein contents of the juice. The effect of the processing conditions considered indicates that separate and interactive effects of the three factors on the qaulity parameters of the juice were significant $(p<0.05)$.
\end{abstract}

Keywords: Hog plum, Ripeness, Machine, Processing, Juice, Quality

\section{INTRODUCTION}

Hog plum (Spondias mombin) tree although mostly grown in Africa, India and Indonesia as orchard tree belongs to the Anacardiaceae family and originated from tropical Americas including the West Indies. The Spondias mombin fruits strive well in arid as well as humid zones (Lima et al., 2016). It has several common names such as "Iyeye" among the Yorubas in Nigeria, "Ashanti" plum in Ghana, while it is commonly referred to as. "jobo" or hog plum in the Caribbean. The fruit has a leathery outer skin and a thin layer of pulp which can be eaten fresh or made into juice, concentrate, jellies and sherbets. The taste from the apple is astringent (Owolarafe et al., 2006), and the seed has an oil content of 31.5\% (Lima et al., 2016). Spondias mombin fruits contain about $13.1 \%$ total carbohydrate which is responsible for its high calorific density. The fruit contains moderate amount of potassium and starch and is also rich in Vitamin C. The fructose, glucose and sucrose content of the fruit amount to about $65 \%$ of the total soluble solids and 2-hexenal is its main flavor compound (Tiburski et al., 2011).

As reported by Ayoka et al. (2008) and Ojo et al. (2018), the study on Spondias mombin tree reveals that it has high medicinal value. The decocted fruits can be drunk or be served as diuretic and febrifuge drink while drinking the decocted bark and leaves can be used as emetic, anti-diarrhea and in the treatment of dysentery. Osuntokun (2018) also reported that Spondias mombin has the ability to prevent or stop the growth of microorganisms like fungi and viruses. The fruits are usually eaten raw and during peak season a lot of the fruit are discarded without being used and hence wasted. Considering the high nutritive value of Spondias mombin fruit, a machine for extraction of juice from the fruit was designed (Olaoye and Owolarafe, 2014). It therefore becomes imperative to evaluate the quality of the juice produced from the machine in relation to some operating conditions of the machine.

\section{MATERIALS AND METHODS}

Fresh graded Spondias mombin samples of different ripeness status were collected within the premises of Obafemi Awolowo University, Ile-Ife, Nigeria. The samples were graded according to ripeness (ripe, about to ripe) by physical observation. After which extraction of the fruits was carried out using developed juice extractor (Olaoye and Owolarafe, 2014) for the fruit. The fruits were 
processed in the juice extractor at three speeds (120, 130 and $150 \mathrm{rpm})$ and three loadings (5, 10 and $15 \mathrm{~kg}$ per time) based on the preliminary experimental runs with the machine. The experimental design is shown in table 1 . The moisture content, crude fiber, protein content, ash content and fat content of the juice were determined.

\section{Determination of Moisture Content of Spondias mombin Juice}

The moisture content of the juice was determined following the procedure reported by AOAC (2003), which was based on the loss of moisture on drying at an oven temperature of $105{ }^{\circ} \mathrm{C}$. A clean flat dish made of silica was dried in an oven for at least one hour, after which it was transferred into a desiccator to cool. The weight of the cooled flat dish was recorded as $W_{1}$. About $2 \mathrm{~g}$ of the sample was introduced into the flat dish and labeled $\mathrm{W}_{2}$. The flat dish and the sample were transferred into the oven set at $105{ }^{\circ} \mathrm{C}$ to dry for three hours. The dried flat dish containing the sample was transferred into the desiccators for cooling. The dish with the dried sample was then weighed on a weighing balance. The process of drying, cooling in desiccator and weighing was repeated until 3 consecutive trials were found to be constant (weight recorded as $\mathrm{W}_{3}$ ).

Percentage moisture content $=\frac{W_{2}-W_{3}}{W_{2}-W_{1}} \times 100$

Table 1: Experimental Design

\begin{tabular}{ll}
\hline Factor & Levels \\
\hline Fruit condition & About to ripe, ripe \\
\hline Machine speed & $120,130,150 \mathrm{rpm}$ \\
\hline Loading & $5,10,15 \mathrm{~kg}$ \\
\hline
\end{tabular}

Determination of Protein Content of Spondias mombin Juice

Over the years, total available nitrogen has been the basis for determining protein content, while the Kjeldahl method has been almost universally applied to determine available nitrogen (FAO, 2003). Protein content can then be determined by multiplying the available nitrogen by a factor (AOAC, 2003).

Based on the standard procedure using the Kjehdahl method, about $0.1 \mathrm{~g}$ of juice sample was weighed into digestion tube. $3.5 \mathrm{~g}$ of $\mathrm{K}_{2} \mathrm{SO}_{4}$ and 3 $\mathrm{g}$ of $\mathrm{Se}$ was added to the sample tube. Concentrated $\mathrm{H}_{2} \mathrm{SO}_{4}$ of about $12 \mathrm{ml}$ was added and shaken with the samples. The exhaust system was attached to the digestion tubes in the rack which was set to the aspirator water. The rack was loaded with exhaust into preheated digestion block at about $420^{\circ} \mathrm{C}$. After five minutes, the water aspirator was turned down while the acid was fuming. This continued until all the samples were cleared with blue/green solution. This process was continuously done for $30-60$ minutes. The rack of tubes with exhaust was removed and put in the stand to cool for $10-20$ minutes using a commercial air blower which increased the cooling. About $80 \mathrm{ml}$ of de-ionized water was added to the tube. After that, steam valve was opened to the digestion tube (Kjeltec 2100, 2200, 2300 and 2400) and distilled for approximately 4 minutes. After the end of distillation cycle, the Kjeltec was closed with steam valve. Titration was carried out with the standardized $\mathrm{HCl}$ (usually $0.1000 \mathrm{~N}$ or $0.2000 \mathrm{~N}$ ) until the blue/grey end point was achieved. The volume of acid used was recorded during the titration (AOAC, 2003).

The calculations are as follows:

$$
\begin{aligned}
& \% N=\frac{(T-B) \times 14.007 \times 100}{\text { Weight of sample }} \\
& \% \text { Protein }=\mathrm{N} \times \mathrm{f} \\
& g N / 1=\frac{(T-B) \times N \times 14.007 \times 100}{\text { Volume of sample }(\mathrm{ml})}(2) \\
& m g N / 100 \mathrm{ml}=\frac{(T-B) \times N \times 14.007 \times 100}{\text { volume of sample }(\mathrm{ml})}(3) \\
& \begin{aligned}
\text { Where } \mathrm{T}= & \text { Titration volume of sample }(\mathrm{ml}) \\
\mathrm{B}= & \text { Titration volume of blank }(\mathrm{ml}) \\
\mathrm{N}= & \begin{array}{l}
\text { Normality of acid to } 4 \text { places of } \\
\text { decimal. }
\end{array} \\
\mathrm{f}= & \begin{array}{l}
\text { Conversion factors for nitrogen to } \\
\text { protein. }
\end{array}
\end{aligned}
\end{aligned}
$$

\section{Determination of Ash Content of Spondias mombin Juice}

About 2-5 g of the sample test was poured into the dish and recorded $\mathrm{W}_{2}$. The sample was evaporated in a boiling water bath. The dried sample was charred over a Bunsen flame until no more soot was given off. With help of a pair of tongs, the dish was transferred into the muffle furnace at 550 
${ }^{\circ} \mathrm{C}$. When the charred sample was completely white in colour, ash formation was assumed completed. Finally the dish with its ash content was weighed and recorded as $\mathrm{W}_{3}$. The process was repeated five times.

Percentage ash $=\frac{W_{3}-W_{1}}{W_{2}-W_{1}} \times 100(\mathrm{AOAC}, 2003)(4)$

\section{Determination of Fat Content of Spondias mombin Juice}

Approximately $3 \mathrm{~g}$ of the sample dried at $70{ }^{\circ} \mathrm{C}$ was ground $(<1 \mathrm{~mm})$ and weighed. The sample was then poured into the extraction thimble (and recorded $W_{1}$ ). The sample was covered with a thin film of defatted cotton wool and attached to the adapters. Extracted cup with boiling chips was weighed as $\mathrm{W}_{2}$. The extracted cup with the sample was inserted into solvent (Ethyl ether) and boiled at $120^{\circ} \mathrm{C}$ for 15 minutes. The solvent was collected and the air valves were opened while vacuum was applied to remove all the solvent in the sample. Finally the extracted cup which contained the fat, oil and chip was dried for 30 minutes at $100{ }^{\circ} \mathrm{C}$. It was cooled and weighed $\left(\mathrm{W}_{3}\right)$

Percentage fat $=\frac{W_{3}-W_{1}}{W_{1}} \times 100$

\section{Determination of Crude Fibre of Spondias mombin Juice}

This was also determined based on the procedure specified by AOAC (2003). About $1 \mathrm{~g}$ of the sample was weighed into a pre-dried crucible of a known weight. The weight of the sample plus crucible was tagged $\mathrm{W}_{1}$. The sample was defatted by placing the crucible in the holder. The crucible sample was attached in cold extraction unit. To make the filtration simpler, 1-3 g of celite was added to the crucible after weighing. A set of crucible was loaded with sample; the stand was hooked on the front of the hot extraction unit. The crucible was fixed to the crucible holder, transferred to the unit and they were attached by pressing the lever down while the valve was in a closed position. $150 \mathrm{ml}$ of hot $0.128 \mathrm{M}$ Tetra oxosulphate (VI) acid was added to valve 1010, 1020 and 1017, respectively. Preheated reagent was poured from the reagent bottle into the column. Then tap water was opened to cool the condenser. To prevent foaming, 2-4 drops of octanol was added and heated to boil for 30 minutes. Then the heater was turned off. The valve was in a vacuum position while the cold water was opened for the suction pump. Filtration then commenced. The sample was washed with $30 \mathrm{ml}$ of water each time with hot de-ionized water in each column. To each sample was added $150 \mathrm{ml}$ of $0.223 \mathrm{M}$ potassium hydroxide or $150 \mathrm{ml}$ of $0.313 \mathrm{M}$ sodium hydroxide in the same way. The crucible was removed and transferred to crucible stand and left at room temperature. The crucible was dried at $100{ }^{\circ} \mathrm{C}$ overnight. The crucible was cooled in a desiccator and weighed $\left(\mathrm{W}_{2}\right)$. The sample was ashed at $500{ }^{\circ} \mathrm{C}$ for at least 3 hours. The crucible was cooled and weighed $\left(\mathrm{W}_{3}\right)$.

Percentage crude fiber $=\frac{W_{2}-W_{3}}{W_{1}} \times 100$

Where

$\mathrm{W}_{1}=$ Weight of sample

$\mathrm{W}_{2}=$ Weight of crucible and residue

$\mathrm{W}_{3}=$ Weight of crucible and ash residue.

\section{Preservation and Storage}

The filtered juice was dispensed into pre-sterilized $75 \mathrm{cl}$ bottles and each corked by means of a Crown-corking machine. The juice sample was preserved naturally by pasteurizing at $75^{\circ} \mathrm{C}$ for 35 minutes to reduce microbial activities. The sample was thereafter cooled in an ice bath and stored under refrigerated condition $\left(4^{\circ} \mathrm{C}\right)$ before analysis (Gold et al., 2000; AOAC, 2003; de Carvalho et al., 2015).

\section{Statistical Analysis}

The data obtained were analyzed using one way ANOVA (Analysis of Variance). All data were expressed as Mean \pm SD and the significant difference was considered at $\mathrm{p}<0.05$.

\section{RESULTS}

Effect of Shaft Speed, Loading Rate and Ripeness on Moisture Content of the Juice Table 2 shows the effect of shaft speed on moisture content of the juice. It could be observed that the moisture content decreased initially as the shaft speed increased from 120 to $130 \mathrm{rpm}$ and later increased as the shaft speed increased from 130 to $150 \mathrm{rpm}$ at different loading rates and degree of ripeness. 
Table 2: Effect of Processing Conditions on the Moisture Content of Juice Extracted

\begin{tabular}{lllc}
\hline Speed $(\mathbf{r p m})$ & Feeding $(\mathbf{k g})$ & \multicolumn{2}{l}{ Moisture Content (\%) } \\
& & About to ripe & Ripe \\
\hline \multirow{2}{*}{$\mathbf{1 2 0}$} & 5 & $89.50 \pm 0.251^{\mathrm{a}}$ & $90.03 \pm 0.201^{\mathrm{b}}$ \\
& 10 & $90.22 \pm 0.532^{\mathrm{a}}$ & $89.20 \pm 0.125^{\mathrm{b}}$ \\
& 15 & $89.87 \pm 0.304^{\mathrm{a}}$ & $92.21 \pm 0.412^{\mathrm{a}}$ \\
\hline \multirow{2}{*}{$\mathbf{1 3 0}$} & 5 & $88.41 \pm 0.322^{\mathrm{b}}$ & $89.88 \pm 0.333^{\mathrm{a}}$ \\
& 10 & $88.44 \pm 0.415^{\mathrm{b}}$ & $88.12 \pm 0.254^{\mathrm{b}}$ \\
& 15 & $89.05 \pm 0.389^{\mathrm{a}}$ & $89.60 \pm 0.399^{\mathrm{a}}$ \\
\hline \multirow{2}{*}{$\mathbf{5 0}$} & 5 & $88.49 \pm 0.308^{\mathrm{b}}$ & $90.09 \pm 0.621^{\mathrm{a}}$ \\
& 10 & $88.87 \pm 0.299^{\mathrm{b}}$ & $89.74 \pm 0.254^{\mathrm{a}}$ \\
& 15 & $89.26 \pm 0.314^{\mathrm{a}}$ & $89.19 \pm 0.614^{\mathrm{b}}$ \\
\hline
\end{tabular}

Values were in triplicates and expressed as Mean \pm S.D. Different superscript shows significant difference at $\mathrm{p}<0.05$.

As presented in the table, increase in loading rate from 5 to $15 \mathrm{~kg}$ increased moisture content of the juice at the different shaft speeds and degrees of ripeness. The highest level of moisture content $(92.21 \pm 0.412 \%)$ was recorded at shaft speed of $120 \mathrm{rpm}$ at $15 \mathrm{~kg}$ loading rate for ripe fruit juice.

Effect of Shaft Speed, Loading Rate and Ripeness on Ash Content of the Juice

As presented in table 3 , the ash content values of the juice at speed of 120,130 and $150 \mathrm{rpm}$ were $0.52,1.06$ and $4.29 ; 0.98,1.03$ and $0.85 ; 0.98,0.85$ and $2.61 \%$, respectively, for about to ripe fruit juice. While for ripe fruit juice, 0.80, 0.50, 0.61;
$2.40,0.99,3.24 ; 0.77,0.68$ and $0.83 \%$, respectively were obtained. Increasing the shaft speed tends to increase the ash content of the juice for different levels of fruit ripeness except at the speed of 130 $\mathrm{rpm}$ for a feeding of $10 \mathrm{~kg}$ that does not follow the trend.

The ash content values at loading of 15,10 and 5 $\mathrm{kg}$ were $4.29,0.85,2.61 ; 1.06,1.06,1.03 ; 0.85,0.52$, and $0.98 \%$, respectively, for about to ripe fruit juice while for ripe fruit juice they were $0.61,3.24$, $0.83 ; 0.50,0.99,0.68 ; 0.80,2.40$ and $0.77 \%$. As presented in the table, highest ash content value was got at the loading rate of $15 \mathrm{~kg}$ (see Table 3).

Table 3: Effect of Processing Conditions on the Ash Content of Extracted Juice

\begin{tabular}{lllc}
\hline Speed (rpm) & Feeding (kg) & \multicolumn{2}{c}{ Ash Content (\%) } \\
& & About to ripe & Ripe \\
\hline \multirow{2}{*}{$\mathbf{1 2 0}$} & 5 & $0.52 \pm 0.082^{\mathrm{b}}$ & $0.80 \pm 0.096^{\mathrm{a}}$ \\
& 10 & $1.06 \pm 0.074^{\mathrm{b}}$ & $0.50 \pm 0.071^{\mathrm{b}}$ \\
& 15 & $4.29 \pm 0.099^{\mathrm{a}}$ & $0.61 \pm 0.054^{\mathrm{b}}$ \\
\hline \multirow{2}{*}{$\mathbf{1 3 0}$} & 5 & $0.98 \pm 0.005^{\mathrm{a}}$ & $2,40 \pm 0.088^{\mathrm{b}}$ \\
& 10 & $1.03 \pm 0.021^{\mathrm{a}}$ & $0.99 \pm 0.055^{\mathrm{c}}$ \\
& 15 & $0.85 \pm 0.053^{\mathrm{a}}$ & $3.24 \pm 0.016^{\mathrm{a}}$ \\
\hline \multirow{2}{*}{$\mathbf{1 5 0}$} & 5 & $0.98 \pm 0.010^{\mathrm{b}}$ & $0.77 \pm 0.033^{\mathrm{b}}$ \\
& 10 & $0.85 \pm 0.017^{\mathrm{b}}$ & $0.68 \pm 0.087^{\mathrm{c}}$ \\
& 15 & $2.61 \pm 0.087^{\mathrm{a}}$ & $0.83 \pm 0.041^{\mathrm{a}}$ \\
\hline
\end{tabular}

Values were in triplicates and expressed as Mean \pm S.D. Different superscript shows significant difference at $\mathrm{p}<0.05$. 
Effect of Shaft Speed, Loading Rate and Ripeness on Fat Content of the Juice

The fat content of the fruit juice as presented in table 4, increased with increase in shaft speed from 120 to130 rpm and later dropped as the speed increases from 130 to $150 \mathrm{rpm}$ at the two degree of ripeness and three loading rates. Also, a fluctuating trend was observed when the loading rate was increased (i.e 5, 10 and $15 \mathrm{~kg}$ ). A decreasing trend was initially observed and later increased as the rate increases. As the fruit condition of ripeness increased from 'about -toripe' to 'ripe', the fat content of the juice increased and thereafter decreased (Table 4). The highest (i.e $1.83 \%$ ) and lowest (i.e 0.05) fat content was recorded at 'about- to- ripe' fruit juice and 'ripe' fruit juice, respectively.

Effect of Shaft Speed, Loading Rate and Ripeness on Fibre Content of the Juice

The fibre content of the juice increased as the shaft speed increases from 120 to $150 \mathrm{rpm}$ as presented in table 5. It also increased as the quantity of fruits fed into the machine increases from 5 to $10 \mathrm{~kg}$ particularly for 'about- to- ripe' condition while there was reduction of the fibre content of the fruit juice with regard to ripe fruits. The fibre content of 'about- to- ripe' fruit juice was also observed to be more than the 'ripe' fruit juice.

Table 4: Effect of Processing Condition on the Fat Content of Extracts

\begin{tabular}{cllc}
\hline Speed (rpm) & Feeding (kg) & \multicolumn{2}{c}{ Fat Content (\%) } \\
& & About- to- ripe & Ripe \\
\hline \multirow{2}{*}{$\mathbf{1 2 0}$} & 5 & $0.15 \pm 0.045^{\mathrm{c}}$ & $0.46 \pm 0.012^{\mathrm{b}}$ \\
& 10 & $1.04 \pm 0.012^{\mathrm{b}}$ & $0.38 \pm 0.011^{\mathrm{b}}$ \\
& 15 & $1.83 \pm 0.023^{\mathrm{a}}$ & $0.72 \pm 0.013^{\mathrm{a}}$ \\
\hline \multirow{2}{*}{$\mathbf{1 3 0}$} & 5 & $1.55 \pm 0.057^{\mathrm{a}}$ & $1.04 \pm 0.022^{\mathrm{b}}$ \\
& 10 & $0.20 \pm 0.062^{\mathrm{c}}$ & $0.32 \pm 0.009^{\mathrm{c}}$ \\
& 15 & $0.49 \pm 0.049^{\mathrm{b}}$ & $1.45 \pm 0.073^{\mathrm{a}}$ \\
\hline \multirow{2}{*}{$\mathbf{1 5 0}$} & 5 & $0.57 \pm 0.095^{\mathrm{b}}$ & $0.97 \pm 0.012^{\mathrm{a}}$ \\
& 10 & $1.37 \pm 0.097^{\mathrm{a}}$ & $0.05 \pm 0.050^{\mathrm{c}}$ \\
& 15 & $1.17 \pm 0.014^{\mathrm{a}}$ & $0.23 \pm 0.071^{\mathrm{b}}$ \\
\hline
\end{tabular}

Values were in triplicates and expressed as Mean \pm S.D. Different superscript shows significant difference at $\mathrm{p}<0.05$.

Table 5: Effect of Processing Condition on the Fibre Content of Extracts

\begin{tabular}{llll}
\hline Speed (rpm) & Feeding (kg) & \multicolumn{2}{c}{ Fibre Content (\%) } \\
& & About- to- ripe & Ripe \\
\hline \multirow{2}{*}{$\mathbf{1 2 0}$} & 5 & $3.81 \pm 0.102^{\mathrm{b}}$ & $5.62 \pm 0.115^{\mathrm{b}}$ \\
& 10 & $3.89 \pm 0.111^{\mathrm{b}}$ & $2.56 \pm 0.094^{\mathrm{c}}$ \\
& 15 & $5.44 \pm 0.105^{\mathrm{a}}$ & $6.53 \pm 0.025^{\mathrm{a}}$ \\
\hline \multirow{2}{*}{$\mathbf{1 3 0}$} & 5 & $6.89 \pm 0.155^{\mathrm{b}}$ & $5.68 \pm 0.154^{\mathrm{a}}$ \\
& 10 & $4.96 \pm 0.098^{\mathrm{c}}$ & $5.54 \pm 0.191^{\mathrm{a}}$ \\
& 15 & $7.38 \pm 0.221^{\mathrm{a}}$ & $4.72 \pm 0.124^{\mathrm{b}}$ \\
\hline \multirow{2}{*}{$\mathbf{1 5 0}$} & 5 & $7.67 \pm 0.168^{\mathrm{a}}$ & $7.14 \pm 0.138^{\mathrm{a}}$ \\
& 10 & $5.49 \pm 0.187^{\mathrm{b}}$ & $2.00 \pm 0.661^{\mathrm{c}}$ \\
& 15 & $5.69 \pm 0.096^{\mathrm{b}}$ & $4.49 \pm 0.133^{\mathrm{b}}$ \\
\hline
\end{tabular}

Values were in triplicates and expressed as Mean \pm S.D. Different superscript shows significant difference at $\mathrm{p}<0.05$. 
Effect of Shaft Speed, Loading Rate and Ripeness on Protein Content of the Juice Extract

The result showed in table 6 revealed that as the shaft speed increases from $120 \mathrm{rpm}$ to $130 \mathrm{rpm}$ in both levels of ripeness (ripe and about- to- ripe), the protein content increased and later decreased from $130 \mathrm{rpm}$ to $150 \mathrm{rpm}$. The protein content increases with increase in rate of loading and level of ripeness.

Table 6: Effect of Processing Condition on the Protein Content of Extracted Juice

\begin{tabular}{llll}
\hline Speed $(\mathbf{r p m})$ & Feeding $(\mathrm{kg})$ & \multicolumn{2}{c}{ Protein Content $\mathbf{( \% )}$} \\
& & About- to- ripe & Ripe \\
\hline \multirow{2}{*}{$\mathbf{1 2 0}$} & 5 & $1.13 \pm 0.020^{\mathrm{a}}$ & $1.30 \pm 0.095^{\mathrm{b}}$ \\
& 10 & $1.21 \pm 0.055^{\mathrm{a}}$ & $1.32 \pm 0.061^{\mathrm{b}}$ \\
& 15 & $1.39 \pm 0.084^{\mathrm{a}}$ & $1.45 \pm 0.044^{\mathrm{a}}$ \\
\hline \multirow{3}{*}{$\mathbf{1 3 0}$} & 5 & $1.27 \pm 0.079^{\mathrm{b}}$ & $1.38 \pm 0.063^{\mathrm{b}}$ \\
& 10 & $1.09 \pm 0.005^{\mathrm{c}}$ & $1.63 \pm 0.058^{\mathrm{a}}$ \\
& 15 & $1.64 \pm 0.077^{\mathrm{a}}$ & $1.75 \pm 0.091^{\mathrm{a}}$ \\
\hline \multirow{2}{*}{$\mathbf{1 5 0}$} & 5 & $1.05 \pm 0.008^{\mathrm{b}}$ & $1.22 \pm 0.041^{\mathrm{a}}$ \\
& 10 & $1.00 \pm 0.075^{\mathrm{b}}$ & $0.96 \pm 0.005^{\mathrm{b}}$ \\
& 15 & $1.35 \pm 0.052^{\mathrm{a}}$ & $1.25 \pm 0.071^{\mathrm{a}}$ \\
\hline
\end{tabular}

Values were in triplicates and expressed as Mean \pm S.D. Different superscript shows significant difference at $\mathrm{p}<0.05$.

\section{DISCUSSION}

Ripeness has a more significant effect on moisture content of Spondias monbin juice extracted, as the moisture content increases with the increase in degree of ripeness. However, the high level of moisture content of the fruit indicates its low solid matter and may increase its rate of perishability and susceptibility to microbial infection. The freshly harvested fruit contains high moisture content but gradually loses the moisture when kept for some time. This result follows the same trend with the one reported by Holloway (1983); Owolarafe et al (2006); Gomes da Silva et al. (2013) and de Carvalho (2015).

The values for ash content obtained were higher than those reported by Oladejo (2009). The difference in geographic location and climatic condition of the area where the fruits were collected might be responsible for the slight difference in the results obtained. The highest ash content value was observed at 'about- to- ripe' Spondias mombin fruit juice, while a steady increase in ash content was recorded for 'about- to- ripe' fruit juice with increasing rate of loading $(5,10$ and $15 \mathrm{~kg}$ ) at shaft speed of $120 \mathrm{rpm}$. Although the values for ash content obtained fluctuate, this inconsistency in the values may be due to inmature fruits mixed up with samples used for processing (Achoba et al., 1992).

The shaft speed, loading rate and fruit ripeness has a fluctuating effect on the fat content of the juice extracted from Spondias mombin fruits. This increase in fat content as the speed of shaft increases was also observed by other authors such as Filgueiras et al.(2001), Melo et al.(2008), and Vasco etal.(2008)

Juice fiber content increases significantly $(p<0.05)$ with increase in shaft speed of the machine. This result which corroborated the findings of Oladejo (2009) may be as a result of the composition of the fruit and vegetable dietary fibre which were predominantly arabinose, galactose and uronic acid, and are soluble in water. The decrease in fibre content with the ripeness of the fruit may be due to increase in the water content due to ripening. Moderatly high crude fibre content of Spondias mombin fruit juice may be due to its high soluble fibre content that had been removed through sieving (Holloway,1983; Olaoye and Owolarafe, 2019).

Shaft speed of up to $130 \mathrm{rpm}$ caused increase in protein content of the juice extracted for all level 
of fruit ripeness. However, the trend decreased with increasing shaft speed up to about $150 \mathrm{rpm}$. Similarly, increasing the rate of loading and degree of ripeness also brought about an increase in the protein content of Spondias mombin fruit juice. This result is similar to that of Oladejo (2009) on proximate composition and micronutrient potential of three locally available fruits in Nigeria.

Statistical analysis of the effect of the processing condition (i.e shaft speed, loading and degree of ripeness ) indicates that the separate and interactive effects of the three factor on the moisture content, ash content, fibre content, fat content and protein content of the juice are significant $(\mathrm{p}<0.05)$.

\section{CONCLUSION}

The study concludes that increasing the shaft speed of the Spondias mombin juice extractor up to $130 \mathrm{rpm}$ causes an increase in the moisture content of the juice extracted, while further increase in the speed causes a decline in the moisture content of the juice. The machine with varying rate of loading (from 5 to $15 \mathrm{~kg}$ ) at different shaft speed and degree of ripeness of the fruit varies directly with the moisture and ash content of the juice extracted. The machine shaft speed as well as loading rate of the fruit varies directly with the protein content of the juice at both conditions of ripeness. Generally, increasing the shaft speed of the machine resulted to an increase in the fat and fiber content of the juice. However, it has a more pronounced effect in 'about-to-ripe' fruits than 'ripe' fruits.

\section{REFERENCES}

Achoba, I.I., Choba, J. A., Lori, J. A., Elegbede, J. A. Kagbu, J. A. 1992. Nutrient composition of black (African) velvet tamarind (Diallum guineense wild) seed and pulp from Nigeria. Journal of Food Biochemistry, 16(4):229-233.

AOAC. 2003. Official methods of analysis. $17^{\text {th }} \mathrm{ed}$. Gaithersburg, Maryland, USA, AOAC International.

Ayoka, A.O., Akomolafe, R.O., Stephen, A., Ukponmwan, O.E. 2010. Medicinal and economic value of Spondias mombin. African Journal of Biomedical Research, 11(2):
$129-136$.

de Carvalho, J.M, Maia, G.A., da Fonseca, A. V., de Sousa, P.H., Rodrigues, S. 2015. Effect of processing on physicochemical composition, bioactive compounds and enzymatic activity of yellow mombin (Spondias mombin L.) tropical juice. Journal of Food Science and Technology, 52(2): 1182 1187.

FAO. 2003. Food energy - methods of analysis and conversion factors. Report of a technical workshop. No 77. Rome.

Filgueiras, H. A. C, Alves, R. E, Oliveira, A. C, Farley, C, Moura, H and Araújo, N. C. 2001. Calidad de Frutas Nativas de Latinoamerica para Industria: Jobo (Spondias mombin L.). Procedings of Interamerican Society for Tropical Horticulture, 43: $72-76$.

Gold, I. L., Enonuya, D.O.M and Bafor, M.E. 2000. Preparation and clarification of date fruit Juice. A paper presented at the Chemical Society of Nigeria (CSN) $23^{\text {rd }}$ Annual International Conference, Awka, Nigeria.

Gomes da Silva, F. V., Silva, S. M., Cabral da Silva, G. and Schunemann, A. P. 2013. Quality and antioxidant activity during ripening of fruits from yellow mombin (Spondias mombin L.) genotypes. Acta Horticulturae. 1012: 843-848. DOI: 10.17660/ActaHorticulturae.2013.1012.1 14

Holloway, D.W 1983. Composition of fruit, vegetable and cereal dietary fibre. Journal of Science of Food and Agriculture, 34: 12361240.

Lima, M. S., Damasio, A. R. L., Crnkovic, P. M., Pinto, M. R., da Silva, A. M., da Silva, J. C. R., Segato S., de Lucas R. C., Jorge, J. A. and Polizeli L.T.M. 2016. Co-cultivation of Aspergillus nidulans recombinant strains produces an enzymatic cocktail as alternative to alkaline sugarcane bagasse pretreatment. Journal of Front Microbiology, 7: 583. doi: 10.3389 / fmicb.2016.00583

Melo, E. D. A., Maciel, M. I. S., Lima, V. L. A. G and Nascimento, R. J. D. 2008. Capacidadeantioxidante de frutas. Revista Brasileira de Ciências Farmacêuticas, 44(2): 193-201. 
Ojo, O.A., Afon, A. G. Ojo, A. B., Ajiboye, B. O., Oyinloye, B. E., Kapp, A. P. 2018. Inhibitory effect of solvent-partitioned fractions of two Nigerian Herbs (Spondias mombin Linn. and Mangifera indica L.) on $\alpha$ amylase and $\alpha$-glucosidase. Journal of Antioxidants, 7(6):73. https:// doi.org/10.3390/antiox7060073.

Oladejo, T. A 2009. Proximate composition and micronutrient potentials of three locally available wild fruits in Nigeria. African Journal of Agricultural Research, 4 (9): 887 892.

Olaoye, I.O. and Owolarafe, O.K. 2014. Development of juice extractor for Spondias mombin fruit. Proceedings of the $15^{\text {th }}$ International and $35^{\text {th }}$ National Conference of the Nigerian Institution of Agricultural Engineers, Akure, Nigeria. Page 744-754.

Olaoye, I.O. and Owolarafe, O.K. 2019. Development of juice extractor for Spondias mombin fruit. Journal of
Multidisciplinary Engineering and Technology (JMEST), 6(5): 10089-10095.

Osuntokun, O. T. 2018. Evaluation of inhibitory zone diameter of crude Spondias mombin (Linn) extract (root, leaf, and stem bark) against thirty infections and environmental isolates. Journal of Bacteriology and Infectious Diseases, 2(1): 8 16.

Owolarafe, O. K. Adeboye, O.C. Adegbenjo, A. 2006. Physical properties and food value of Spondias mombin L. - An underexploited fruit of Nigeria. Journal of Food Science and Technology, 43(6): 626-638.

Tiburski, J.H., Rosenthal, A., Deliza, R., de Oliveira, R.L. 2011. Nutritional properties of yellow mombin (Spondias mombin L.) pulp. Food Research Industrial, 44(7): 2326 2331.

Vasco, C., Ruales, J. and Kamal-Eldin, A. 2008. Total phenolic compounds and antioxidant capacities of major fruits from Ecuador. Journal of Food Chemistry, 111(4): 816-823. 